\title{
Character Association among the Yield and Yield Attributes in Fenugreek (Trigonella foenum- graecum $\mathrm{L}$.)
}

\author{
Rajneesh Shukla*, V.P. Pandey and Akshay Jain \\ Department of Vegetable Science Narendra Deva University of Agriculture and Technology \\ Kumarganj, Faizabad-224229, (U.P.), India \\ *Corresponding author
}

\section{A B S T R A C T}

The experimental material consisted of a total of 49 genotypes and three checks in seven blocks accomodating seven genotypes and three checks in each block, conducted in Augmented Block Design with three replications at the Main Experiment Station,

\section{Keywords}

Fenugreek GCV, PCV, Heritability, Genetic advance.

Article Info

Accepted:

12 September 2017 Available Online:

10 November 2017 Department of Vegetable Science, Narendra Deva University of Agriculture and Technology, Kumarganj, Faizabad (U.P.). The characters studied were Plant height (cm), number of branches per plant, days to $50 \%$ flowering, pods per plant, pod length, seeds per pod, days to maturity, 1000 seed weight $(\mathrm{g})$, seed yield per plant $(\mathrm{g})$,seed yield (q/ ha). Data were analyzed statistically for their mean, range, coefficient of variation, heritability, genetic advance, and genetic advance as per cent of mean and genetic divergence using non-heirarchical Euclidean cluster analysis. Analysis of variance for the design of experiment indicated highly significant differences among genotypes for all the characters. Based on mean performance for yield and yield components, the JFG-15, NDM-27, AM298, AM-293 and AM-30 were identified as most promising genotypes for seed yield per plant. The maximum genotypic and phenotypic coefficient of variation was observed for branches per plan, and yield per plant and lowest for days to maturity and Days to $50 \%$ flowering, respectively.

\section{Introduction}

India has been known as land of spices since very early period of recorded history. The history of Indian spices dates back to the beginning of human civilization. In India, it occupies an area of about 81.2 thousand hectare with $118.4 \mathrm{mt} / \mathrm{ha}$ production and $1.5 \mathrm{mt} /$ ha productivity (Anonymous 2010-11) the value of spices including spices product such as oils, oleoresins and curry powder amount to over 4200 corers (Spices board Kochi). Among the seed spices fenugreek (Trigonella foenum- graecum L.) belongs to family Fabaceae, 2n=16 (Fryer, 1930).
It has been originated in Egypt. However, in India it is mainly grown in Rajasthan, Madhya Pradesh, U.P., Gujarat, and Punjab; Rajasthan claims the monopoly in production accounting for about $80 \%$ of fenugreek produce in the country. The seeds are used as spice and condiment to improve the flavour and nutritive value of food, fried seeds with a small quantity of oil is used for seasoning vegetables. Being due to its mucilaginous, demulcent diuretic, carminative, astringent, emollient and aphrodisiac properties seeds are also used in preparation of several ayurvedic 
medicines. Fenugreek which from the actual spice is rich source of vitamin $\mathrm{A}, \mathrm{C}$ and $\mathrm{B}_{2}$ (Aykroyd, 1963), protein (Rao and Sharma 1987). Along with its another cultivated spices Trigonella corniculata L. commonly known as kasuri or champa methi differing in growth habit/pod seed size and yield potential and serves as multipurpose crop. Fenugreek is grown during Rabi or winter season as leafy vegetable, seed or leaf spices for human consumption (Som Maity, 1986, Pandey, 1993) fodder for the animal (Jatasra and Lodhi, 1980) and green manure to enrich the soil fertility through nitrogen fixation, i.e., above $283 \mathrm{~kg}$ N/ha (Gill and Singh, 1988 and Kohli, 1983).

\section{Materials and Methods}

The experimental material comprised of 49 genotypes of fenugreek and 3 checks was evaluated at Main Experiment Station of Department of Vegetable Science, at Narendra Deva University of Agriculture \& Technology, Narendra Nagar (Kumarganj), Faizabad (U.P.). Geographically the experimental site falls under humid subtropical climate and is located in between $24.47^{\circ}$ and $26.56^{\circ} \mathrm{N}$ latitude, and $82.12^{\circ}$ and $83.58^{\circ} \mathrm{E}$ longitude at an altitude of $113 \mathrm{~m}$ above the mean sea level in the Gangetic Alluvial Plains of eastern Uttar Pradesh. The experiment was conducted in Augmented block design with 7 block to evaluate 49 genotypes of fenugreek and 3 checks. Individual block dimension was row to row spacing of $30 \mathrm{~cm}$ and plant to plant spacing of $20 \mathrm{~cm}$. Recommended doses of F.Y.M. and fertilizers were applied. The required pesticides and fungicides were used, as and when required to save the crop from pests and diseases, respectively. The observations were recorded from five randomly selected plants from each treatment in each block. Observations on the following parameters were recorded using the standard procedure:
Plant height $(\mathrm{cm})$, Number of braches per plant, Days to $50 \%$ Flowering, Number of pods plant ${ }^{-1}$, Length of pod $(\mathrm{cm})$, Number of seed pod $^{-1}$, Days to maturity, 1000 seed weight $(\mathrm{g})$, Seed yield per plant $(\mathrm{g})$, Seed yield $\left(\mathrm{qha}^{-1}\right)$. The analysis of variance for different characters in "Augmented Design" was done according to Federer (1956). The mean squares for error was subtracted from the mean squares due to varieties and then difference was divided by number of replications for obtaining the genotypic variance, which was calculated according to the method suggested by Burton (1952). Environmental variance is the mean squares due to error. Phenotypic variance was calculated by adding genotypic variance and environmental variance, which was suggested by Burton and de Vane (1953). Heritability in broad sense according to Hanson et al., (1956), Genetic advance according to Johnson et al., (1955).

\section{Results and Discussion}

The analysis of variance for Augmented Design was carried out for ten characters. The variation due to the blocks were highly significant for branches per plant, pods per plant, pod length, plant height, test weight, yield per plant and seed yield (q / ha) and non-significant for days to $50 \%$ flowering, seed per pod and days to maturity and checks were highly significant for test weight, yield per plant and seed yield (q/ha), pod length and plant height were significant, the other are non-significant.

The genotypic and phenotypic coefficient of variations was computed to assessed to existing variability in the genotypes (Table 1) The high magnitude coefficients of variation at genotypic level as well as phenotypic level in case of Number of branches/plant. The phenotypic coefficient of variation was higher than genotypic coefficient of variation, which 
indicates possibilities for obtaining very high selection response in respect of these traits. Number of branches/plant (26.85) showed highest phenotypic coefficient of variation followed by yield per plant (22.088), and lowest phenotypic coefficient of variation observed days to maturity (1.26) followed by day to maturity (1.43).While highest genotypic coefficient of variation observed for Number of branches/plant (22.92) followed by seed yield q/ha (21.43), and lowest genotypic coefficient of variation observed days to maturity (-1.02) followed by Days to $50 \%$ flowering. (8.21).

The high estimates of GCV and PCV for these traits were reported by several workers. The similar, results were reported by Mehta $e t$ al., (1992), Singh et al., (1992).

Table.1 Estimates of range, general mean, coefficient of variation, heritability genetic advance and genetic advance in per cent of mean for ten characters in fenugreek

\begin{tabular}{|c|l|c|c|c|c|c|c|c|c|}
\hline \multirow{2}{*}{ S. No. } & \multirow{2}{*}{ Characters } & \multirow{2}{*}{ Mean } & \multicolumn{2}{|c|}{ Range } & \multicolumn{2}{|c|}{$\begin{array}{c}\text { Coefficient of } \\
\text { variation }\end{array}$} & Heritability & $\begin{array}{c}\text { Genetic } \\
\text { Genetic } \\
\text { Advance } \\
\text { Advance } \\
\text { as \% of } \\
\text { mean (Ga) }\end{array}$ \\
\cline { 4 - 9 } & & Lowest & Highest & GCV & PCV & & \\
\hline $\mathbf{1}$ & $\begin{array}{l}\text { Days to 50\% } \\
\text { Flowering }\end{array}$ & 61.607 & 58.781 & 64.181 & 0.748 & 1.431 & 0.273 & 0.637 & 1.033 \\
\hline $\mathbf{2}$ & $\begin{array}{l}\text { Branches } \\
\text { /Plant }\end{array}$ & 2.624 & 1.419 & 4.686 & 22.928 & 26.858 & 0.729 & 1.339 & 51.674 \\
\hline $\mathbf{3}$ & Pods/ Plant & 60.645 & 80.590 & 38.590 & 15.716 & 18.235 & 0.7429 & 21.724 & 35.760 \\
\hline $\mathbf{4}$ & $\begin{array}{l}\text { Pod Length } \\
\text { (cm) }\end{array}$ & 11.188 & 12.981 & 8.981 & 7.684 & 9.307 & 0.682 & 1.871 & 16.749 \\
\hline $\mathbf{5}$ & Seeds/ Pod & 17.022 & 22.432 & 12.952 & 2.138 & 11.828 & 0.033 & 0.174 & 1.020 \\
\hline $\mathbf{6}$ & $\begin{array}{l}\text { Days to } \\
\text { Maturity }\end{array}$ & 98.401 & 94.811 & 101.411 & -1.024 & 1.263 & -0.657 & -2.155 & -2.190 \\
\hline $\mathbf{7}$ & $\begin{array}{l}\text { Plant Height } \\
\text { (cm) }\end{array}$ & 56.201 & 31.086 & 79.152 & 19.021 & 22.024 & 0.746 & 24.273 & 43.370 \\
\hline $\mathbf{8}$ & $\begin{array}{l}\text { Test Weight } \\
\text { (g) }\end{array}$ & 8.095 & 10.148 & 5.548 & 11.122 & 12.486 & 0.793 & 2.114 & 26.154 \\
\hline $\mathbf{9}$ & $\begin{array}{l}\text { Yield/ Plant } \\
\text { (g) }\end{array}$ & 8.780 & 12.340 & 4.666 & 21.533 & 22.088 & 0.950 & 4.889 & 55.420 \\
\hline $\mathbf{1 0}$ & $\begin{array}{l}\text { Seed Yield } \\
\text { Q/ha }\end{array}$ & 13.111 & 18.515 & 7.005 & 21.435 & 21.996 & 0.950 & 7.263 & 55.146 \\
\hline
\end{tabular}

The estimates of heritability in broad sense were higher for all the characters in the environments. High values of heritability suggest the major role of genotypic constitution in the expression of character. In the present study, the estimates of heritability in broad sense ranged from 0.95 (yield/plant) to 0.03 (seeds/pod).The findings of present study are in agreement with those of Baswana et al., (1984), Sharma et al., (1990) and Mehta et al., (1992).

The highest Genetic advance was expressed for plant height followed by followed by yield per plant and test weight. The remaining characters showed moderate estimate of genetic advance in percent of mean. Genetic advance in percent of mean was highest in 
case of plant height $(30.00 \%)$ followed by yield per plant $(29.16 \%)$ and test weight $(25.72 \%)$. The findings of present study are in agreement with those of Baswana et al., (1984), Singh et al., (2000) and Sarda et al., (2008).

\section{References}

Anonymous (2010-2011) Data base, National Horticulture Board, Gurgaon.

Aykroyd, W.R. (1963). The nutritive value of Indian foods and planning for statisfactory diets. ICMR Special Report, Series No.42.

Baswana, K.S., Padita, M.L. and Malik, Y.S. (1984).Variability studies in fenugreek. Haryana J. Hort. Sci., 13 (1-2): 78-81.

Burton, G.W. and de Vane. E.W. (1953). Estimating Heritability in tall fescue (Festuca arundinacea) from replicated clonal material. Agron. J., 45 478-481.

Feeder, W.T. (1956). Augmented design, "Hawain Planters" Record, 55:191-208.

Fryer, J.R. (1936). Chromosome Atlas of flowering Plants. George Allen and Urwin, London, pp 519.

Gill, S.S. and Singh, H. (1988). Effect of planting date and leaf cutting on the seed yield of methi hield of methi (Trigonella foenum graecum L.) J. Res. Punjb Agric., Univ., Ludhiana, 25: 206-
209.

Hanson, C.H., Robinson, H.F. and Comstock, R.E. (1956). Biometrical studies of yield in segregating population of Korean Lespedeza Agron. j., 48: 268271.

Jatasara, D.S. and Lodhi, G.P.(1980).Sutiable fodder for grain crop for late sowing. Haryana Fmg. 9(12): 7.

Johnson, H.W., Robinson, H.F. and Comstock R.K. (1955) Genotypic and phenotypic correlation in soyabean and implication in selection. Agron. J. 47: 477-488.

Maurya, K.R. and Singh, R.P. (1989). Correlation and heritability studies in fenugreek. Indian Cocoa Arecanut Spices J. 13 (2): 53-57.

Pandey, S.C. (1993). Improvement of leafy vegetables, In Advances in Horticulture (K.L. Chadha and G. Kallo, Eds) pp. 325-342. Malhotra Publishing House. New Delhi.

Rao, P.U. and Sharma, R.D. (1987). An evaluation of protein quality of fenugreek seed (Trigonella foenum graecum L.) and their supplementary effects. Food Chemistry, 24 (1): 1-9.

Some, M.G. and Maity. T. K. (1996). Fenugreek In: Vegetable crops in Indian (T.K. Bose and M.G. Som, eds.) Naya Prakash. Calcutta, India, pp 680-686.

\section{How to cite this article:}

Rajneesh Shukla, V.P. Pandey and Akshay Jain. 2017. Character Association among the Yield and Yield Attributes in Fenugreek (Trigonella foenum- graecum L.). Int.J.Curr.Microbiol.App.Sci. 6(11): 1375-1378. doi: https://doi.org/10.20546/ijcmas.2017.611.164 